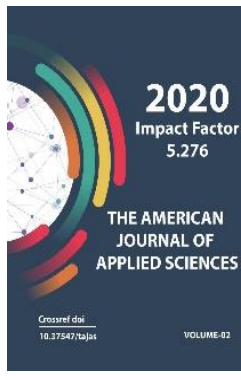

Copyright: Original content from this work may be used under the terms of the creative commons attributes 4.0 licence.

\section{Analysis And Directions Of Development Of The Practice Of Attracting Capital From The Financial Market Of Joint-Stock Companies. Evidence From Uzbekistan}

\author{
Buvsara Tashmuradova \\ Professor, Department Of Corporate Finance And Securities, Tashkent Institute Of Finance, \\ Tashkent, Uzbekistan \\ Omonullo Hamdamov \\ PhD, Department Of Corporate Finance And Securities, Tashkent Institute Of Finance, \\ Tashkent, Uzbekistan
}

\title{
ABSTRACT
}

The paper describes the economic importance of attracting financial resources from the national and international financial markets by joint stock companies operating in the Republic of Uzbekistan. The current situation with the attraction of capital from the international financial markets by companies in the financial sector has been analyzed and key conclusions have been drawn. In national practice, the existing shortcomings in the financing of companies on the basis of debt instruments have been studied and scientific proposals have been developed to address them.

\section{KEYWORDS}

Financial market, Digital economy, Eurobond, Investment policy, Global rating, Innovation, Price, Securities, Benchmar.

\section{INTRODUCTION}

In Uzbekistan, special attention is paid to providing joint stock companies with additional financial resources and raising the international sovereign credit rating by attracting financial resources from the international capital market. The transformation of joint-stock companies into participants in the international financial market will increase their ability to introduce innovative technologies into production processes, as well as increase the process of international integration.
It should be noted that the formation and effective use of financial resources from domestic sources is important in the development of the country's economy, but the growing demand for financial resources creates the need to attract financial resources from international capital markets. Today, for the first time in the history of Uzbekistan's independence, the first positive results have been achieved by placing corporate Eurobonds on the international stock exchange. 
As the President of the Republic of Uzbekistan Sh. Mirziyoyev noted, "For the first time, Uzbekistan has received an international credit rating and successfully placed $\$ 1$ billion worth of bonds in the world financial markets. The Organization for Economic Cooperation and Development (OECD) has improved Uzbekistan's credit risk rating for the first time in 10 years. Deep structural reforms have begun in energy, oil and gas, geology, transport, road construction, agriculture and water management, drinking water and heat supply, and a number of other sectors. [1].

Uzbekistan is carrying out large-scale economic reforms and structural changes aimed at ensuring the stability of macroeconomic stability and radically improving the investment climate in the country for private, including foreign investment. Nevertheless, it is necessary to obtain corporate ratings by leading banks and large enterprises of Uzbekistan, as well as a sovereign credit rating of the country, which significantly expands the country's ability to attract foreign investment and debt without state guarantees. Based on the above, it should be noted that in order to ensure the economic development of the country, it is necessary to identify existing problems and shortcomings in the development of the capital market, as well as to develop comprehensive measures to address them. In addition, it is expedient to develop practical recommendations for the use of foreign market development in national practice, effectively using foreign experience.

\section{MAIN PART}

As scholars who have studied the characteristics of the modern capital market have noted, "the capital market is a broad concept not only in economics but also in practice, and it covers a wide range of activities, depending on the goals and objects of research." [2]. Authors of scientific articles on the capital market, its composition and characteristics Lapshina Z.V. and Praxt K.S. According to them, "the capital market is a part of the financial market, in which the circulation of funds with a term of more than one year is carried out. [3]".

German economists L. Perridon and M. Steine describe the capital market in their scientific work on corporate finance: "The capital market is an organized exchange trade in which securities are traded for more than a year [4". According to RR Rubtsov, the author of many scientific works on the fundamentals of financial market regulation in the Russian Federation, "Financial market is a set of economic relations and institutions related to the movement of money capital." [5] According to Ivanova VV, author of the scientific monograph on modern views of the financial market and its structural segments, "the financial market is the field of financial transactions using financial instruments [6]." According to F. Mishkin, the author of many scientific publications on the international financial market and institutions, their organizational and economic bases, "the financial market is a market that serves to transfer money from people with surplus funds to those who lack money [7]".

It should be noted that in Uzbekistan, too, many economists are conducting research on the capital market and its institutional basis and main features. Including i.f.n. According to SP Abdullayev, the financial market will ensure the movement of money in the economy, as well as the "uninterrupted" formation, effective use and investment of financial resources. It ensures the free movement of money invested between different areas of economic activity, the free and rational use of financial resources. In turn, the mobilization of money as capital for production strengthens economic potential, accelerates innovation, scientific and technological progress, and on this basis serves to further increase the welfare of the 
people [8]". Prof. Burxanov A. and Hamdamov $O$ in the textbook "Financial Management" the main sources of information are the indicators that characterize the situation in the financial market in the effective organization of financial management in joint stock companies. The system of information indicators in this group helps enterprises to make management decisions on issues such as the formation of a long-term financial investment portfolio, the implementation of short-term capital investments [9].

\section{RESULTS AND DISCUSSIONS}

Modernization of the corporate sector of the economy, technical and technological renewal, sharp increase of its competitiveness, increase of export potential, organization of new productions based on innovative and energy-saving technologies, development of new types of goods in demand in the world market. The investment policy pursued by the banking system in ensuring economic stability is bearing fruit. In 2019, commercial banks will allocate 88.3 trillion soums to finance investment projects of enterprises in the real sector of the economy. soums or 2.3 times more than in
2018 due to investment loans, including 2.1 bln. soums from foreign credit lines. Loans in the amount of USD were allocated. In 2018, the corporate sector will provide a total of 38.8 trillion soums to joint stock companies. UZS, which is 2.4 times more than in 2017 (Figure 1).

At the same time, the investment activity of banks is primarily focused on ensuring timely and full financing of projects included in the Sectoral Development, Localization and Regional Development Programs. In 2014, commercial banks provided a total of 8547.2 billion soums for modernization, technological and technical re-equipment of enterprises. soums or 1.2 times more than in 2013. In 2016, a total of 12,200.6 billion soums of investment loans were issued in the country, which is $20 \%$ more than in 2015. By 2017, we can see that this figure has exceeded 14,400 billion soums.

The volume of shares of commercial banks sold on the secondary exchange market of Uzbekistan in 2015 amounted to 37.35\%. The rest of the placement of newly issued shares of banks accounted for the primary market share.

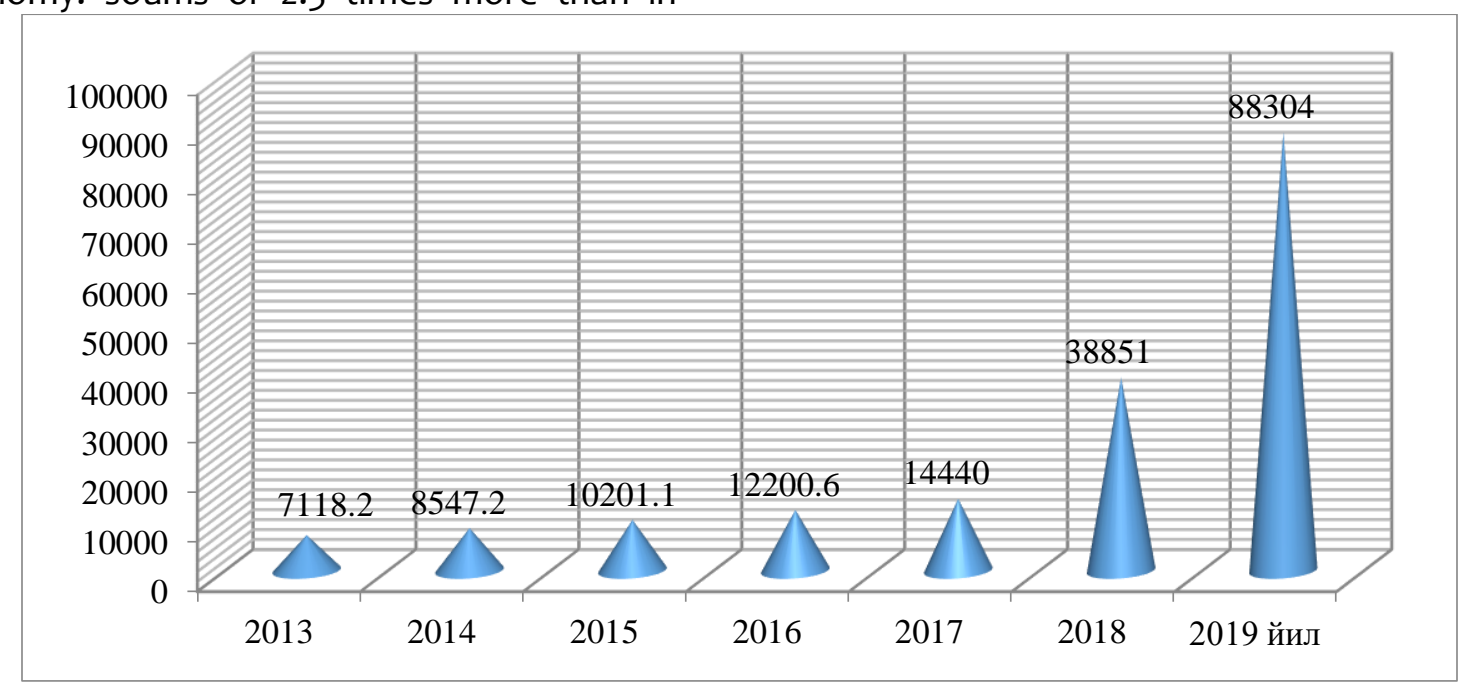

Figure 1. Volume of investment loans provided by commercial banks to corporate sector joint stock companies (in billion soums)

\section{Source: Central Bank of Uzbekistan}


Figure 2 below shows an analysis of the volume of trades in bank securities on the Republican Stock Exchange "Tashkent", which shows that until the end of 2018, the bulk of trades are carried out by commercial banks. In 2016, the total volume of securities transactions by the bank amounted to 151.8 billion soums. At the end of 2018, their volume amounted to 591.6 billion soums. soums and the share of banks in the total trade volume was $86.1 \%$.

In 2019, despite a slight decrease in the volume of trades in bank securities, the volume of trades of banks amounted to 319.5 billion. soums, or $72.8 \%$ of the total trade volume. The advantage of organizing the participation of commercial banks in the interests of innovative development of enterprises in Uzbekistan is that they can participate not only as traditional lenders and financial market operators, but also as institutional investors, investment advisers, investment intermediaries and other professional participants in the securities market. It should be noted that in recent years, large-scale work has been carried out to sell commercial banks to international investors, gradually reduce the share of the state in the authorized capital.

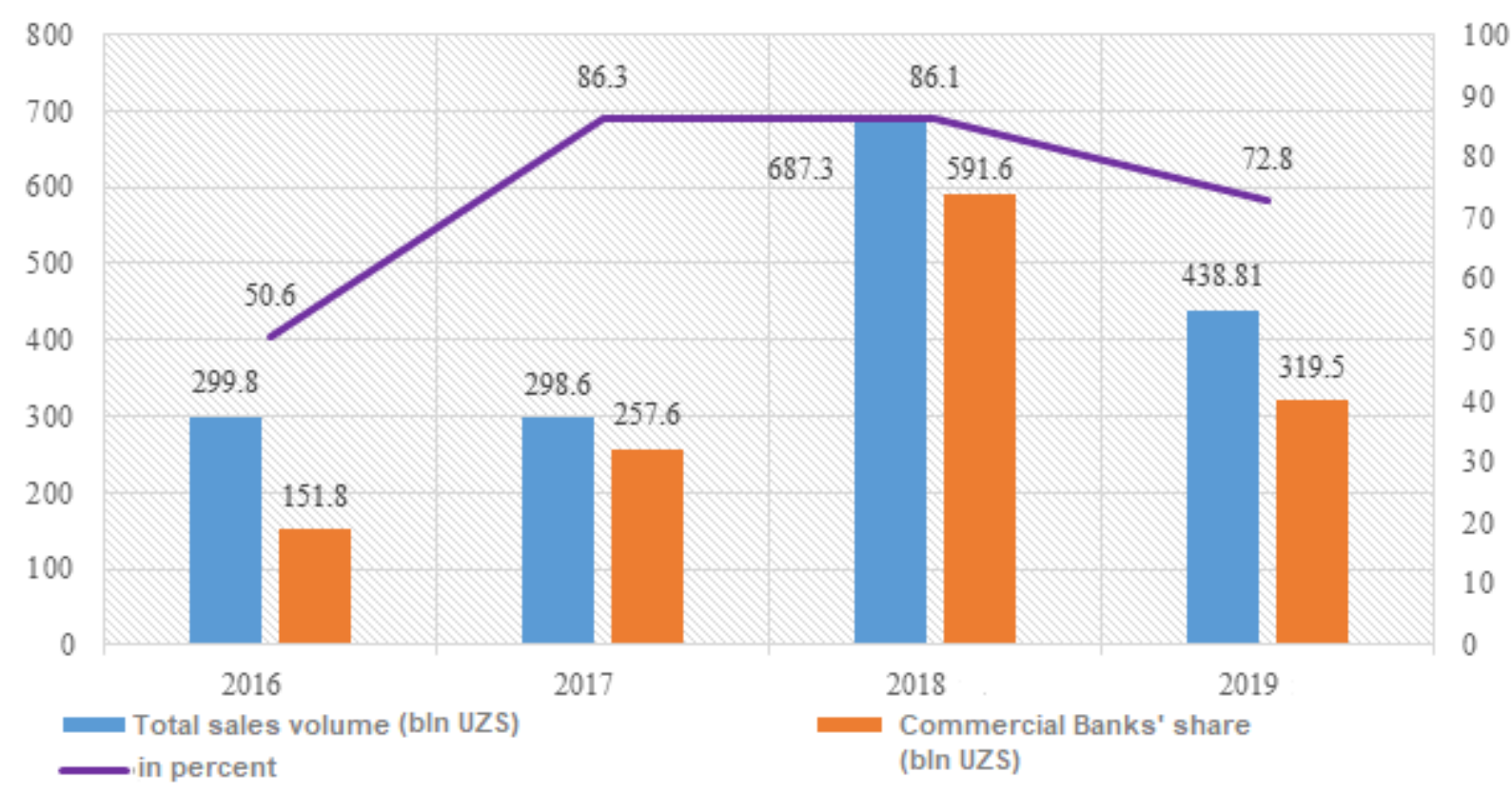

Figure 2. The volume of trading in securities of the banking sector of the economy on the stock exchange in 2016-2019 Source: Uzbekistan stock exchange

However, the opposite is true of the state's share in the charter capital of Asaka Bank, which was selected as the object of analysis. In 2015, this figure was 67\%, and in 2019 it will increase to $98.18 \%$. In 2019 , the volume of attracting financial resources from the stock market by joint-stock companies in the financial sector of the economy increased by $16 \%$ compared to 2018 and exceeded 281.9 billion soums compared to previous years. Of these, a total of 7,567 transactions were recorded. The most active banks in terms of the number of transactions were JSCB 
"Uzpromstroybank", JSCB "Khamkorbank" and JSCB “Ipteka-Bank", which made 2,763, 2002 and 1786 transactions with shares, respectively.

It should be noted that the high share of the state in the charter capital of enterprises limits the aspiration to modern financial instruments in attracting financial resources from the capital market and an independent approach to innovation. In 2019, a total of 18 commercial banks of the country as a issuer of shares traded on the Republican Stock Exchange "Tashkent". According to

\section{Table 1}

The state of attraction of financial resources through the stock market by enterprises of the financial sector of the economy in 2019 [12]

\begin{tabular}{|c|c|c|c|c|}
\hline № & Issuer & $\begin{array}{l}\text { Number of share (in } \\
\text { thousands) }\end{array}$ & Amount (in mln UZS) & $\begin{array}{l}\text { Number of } \\
\text { agreements }\end{array}$ \\
\hline 1. & Agrobank JSCB & 7449,1 & 8073,5 & 91 \\
\hline 2. & Davr-Bank PJSCB & 2717,9 & 13589,9 & 7 \\
\hline 3. & Hamkorbank JSCB & 933713,8 & 36890,1 & 2002 \\
\hline 4. & HI-TECH BANK & 10319,1 & 16195,5 & 14 \\
\hline 5. & “Ipoteka-bank" ATIB & 1809055,1 & 2794,1 & 1786 \\
\hline 6. & Kapitalbank JSCB & 71639,1 & 74252,7 & 21 \\
\hline 7 . & Microcreditbank JSCB & 103,2 & 110,726 & 43 \\
\hline 8. & Uzpromstroybank JSCB & 312108,5 & 5908,6 & 2763 \\
\hline 9. & Ravnaq-Bank Public Utility Company & 14847,9 & 14850,2 & 18 \\
\hline 10. & Trustbank XAB & 12834,2 & 14554,7 & 152 \\
\hline 11. & Turkiston Public Association & 50720,7 & 50720,8 & 65 \\
\hline 12. & Turonbank JSCB & 38,9 & 83,7 & 71 \\
\hline 13. & JSC “Urgenchkormmash” & 100,0 & 1031,7 & 1 \\
\hline 14. & "Silk Road" AITB & 1791691,1 & 18147,9 & 43 \\
\hline 15. & "Aloqabank" ATV & 139,3 & 58,9 & 198 \\
\hline 16. & Savdogarbank ATV & 43,3 & 6,5 & 68 \\
\hline 17. & JSCB “Qishloq Qurilish Bank” & 134,9 & 24,2 & 119 \\
\hline \multirow[t]{2}{*}{18.} & “Universal bank" JSCB & 4932,7 & 24663,8 & 105 \\
\hline & TOTAL & 5022589,3 & 281958,2 & 7567 \\
\hline
\end{tabular}


Unfortunately, the results of the analysis show that the size of the corporate bond market, which is currently used in Uzbekistan as an important source of funding by joint stock companies, is several times lower than in the countries with the lowest share among Asian countries. As of January 1, 2020, a total of 164 corporate bonds of 103 issuers worth 848.9 billion soums were issued in the country (Figure 3). Of these, 116 were completely shut down and 27 were canceled. Currently, the number of bonds in circulation is 13 , with a total value of 488 billion soums. In particular, in 2019, Infin Bank will invest 100 billion soums. UZS 50 billion from Asia Alliance Bank UZS and UZB "Uzpromstroybank" 150 bln. UZS worth of corporate bonds were registered.

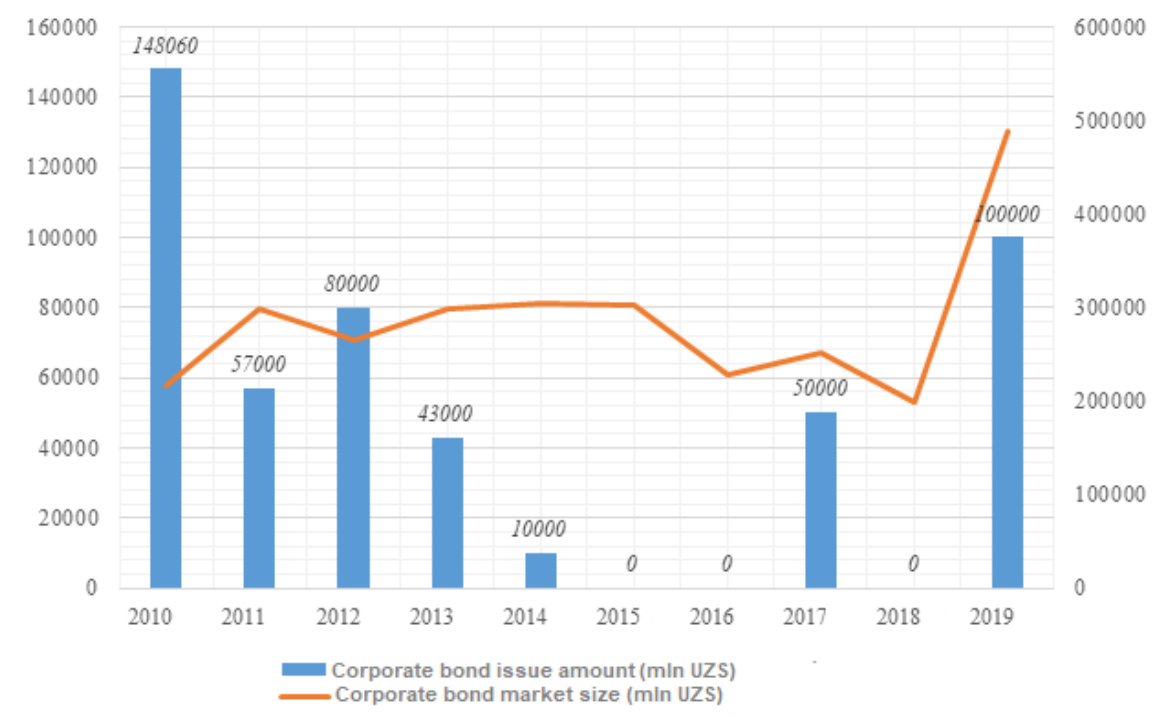

Figure 3. The state of the corporate bond market in Uzbekistan in 2010-2019 (in million soums)

In 2012-2017, a total of 183,000.0 million soums of corporate bonds were issued, of which $27.3 \%$ of the total issued bonds fell to the real sector of the economy, and the remaining $72.7 \%$ to the financial sector, to be more precise, to commercial banks. . Another noteworthy aspect is that during 2015-2016 and 2018, no bonds or corporate bonds were issued by joint stock companies operating in

either the real sector or the financial sector. In May 2017 alone, Uzavtosanoat JSC issued 50,000 corporate bonds.

In 2019, InfinBANK's corporate bonds were issued. The issuance of bonds was another important step in the bank's activities to strengthen the bank's position in the local banking and stock markets. Thus, in February 2019, the Capital Market Development Agency of the Republic of Uzbekistan issued a total of 100 billion soums in the amount of 100,000 units. Issuance of corporate bonds of JSCB "Invest Finance Bank" in the national currency amounted to UZS 1 billion.

Enterprises themselves cannot solve the problem of attracting the required amount of investment in the form of long-term loans, leasing equipment or investments in their securities. Of all the categories of financial institutions, only commercial banks are able to provide practical assistance to issuing companies in financing renewal programs due to the high level of capitalization, high diversification of their activities, as well as the availability of the necessary human and 
information resources. The second group of factors leading to the strengthening of the role of banks as a locomotive for institutional strengthening of the country's stock market is the growing interest of the banking sector in further integration of industrial and financial capital, without which the Uzbek economy is unlikely to take its rightful place.

In recent years, the charter capital of most banks has been based on government decisions through closed subscriptions through the placement of securities among pre-known, limited number of investors without public announcement and without an advertising campaign. It should be noted that such an increase in the authorized capital of banks has led to an increase in the share of the state, which in turn is a negative factor affecting the development of the secondary stock market. At present, Asaka Bank invests in government securities, which are the most reliable intermediaries in the securities market of the Republic of Uzbekistan, through the Currency Exchange of the Republic of Uzbekistan. The Bank is a Dealer at the Currency Exchange of the Republic of Uzbekistan and provides brokerage services to investors (residentslegal entities) in the government securities market and in the market of state mediumterm treasury bonds. Figure 4 shows an analysis of the main financial indicators of Asaka Bank, which shows the capital dynamics of the bank for 2014-2019, including the growth of authorized capital and changes in net profit over the years.

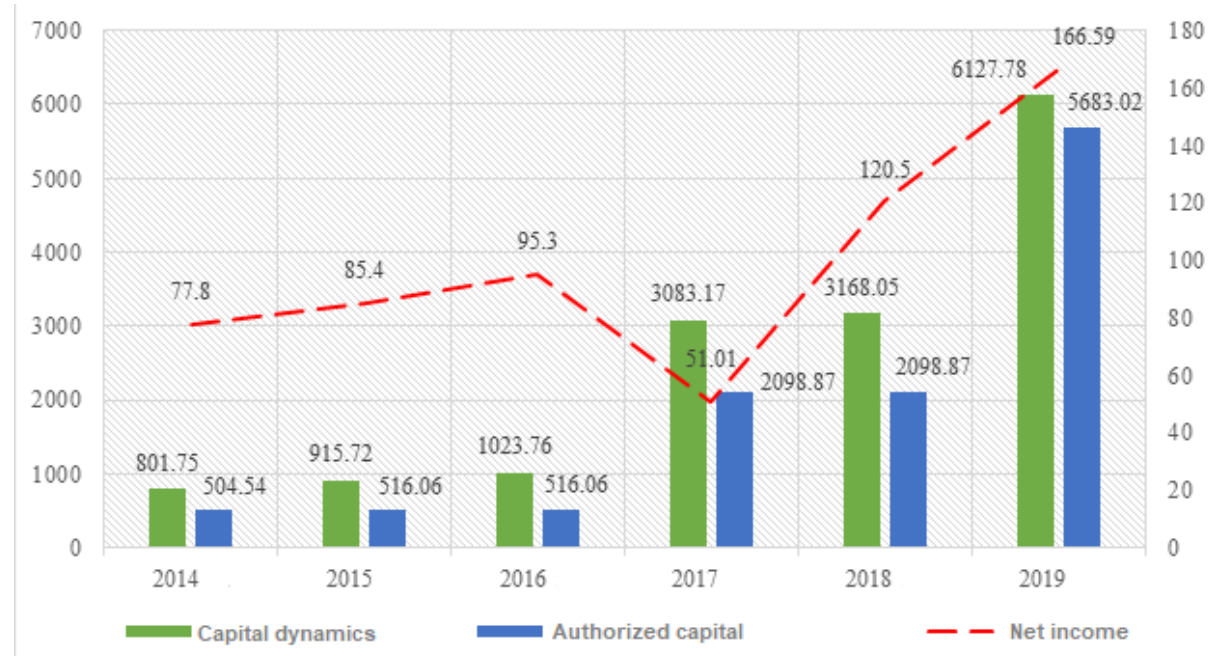

Figure 4. Dynamics of growth of total capital, authorized capital and net profit of Asaka Bank in 2014-2019 (billion soums)

JSCB "Uzpromstroybank" has been preparing for the issuance of international corporate bonds on the basis of recommendations of international investment banks (financial consultants) such as JP Morgan, Citigroup, Commerzbank, Raiffeisen Bank. As of November 25, 2019, more than 150 investors have placed orders for $\$ 1.2$ billion on international bonds issued by
Uzpromstroybank in the amount of $\$ 300$ million, and international bonds have been placed at a coupon rate of $5.75 \%$. . These international bonds were placed among investors from the UK ( 30 per cent), the US (16 per cent), Europe (40 per cent) and Asia and the Middle East (14 per cent). Analyzing the buyers of Eurobonds issued by Uzpromstroybank JSCB, we consider it 
expedient to single out the legal entities included in the international Top 5. These include Sparinvest Holdings SE, a well-known Luxembourg company, and Sun Life Financial Inc. of Canada. (SLF), Clariden Leu AG of Switzerland, Standard Life Aberdeen plc of

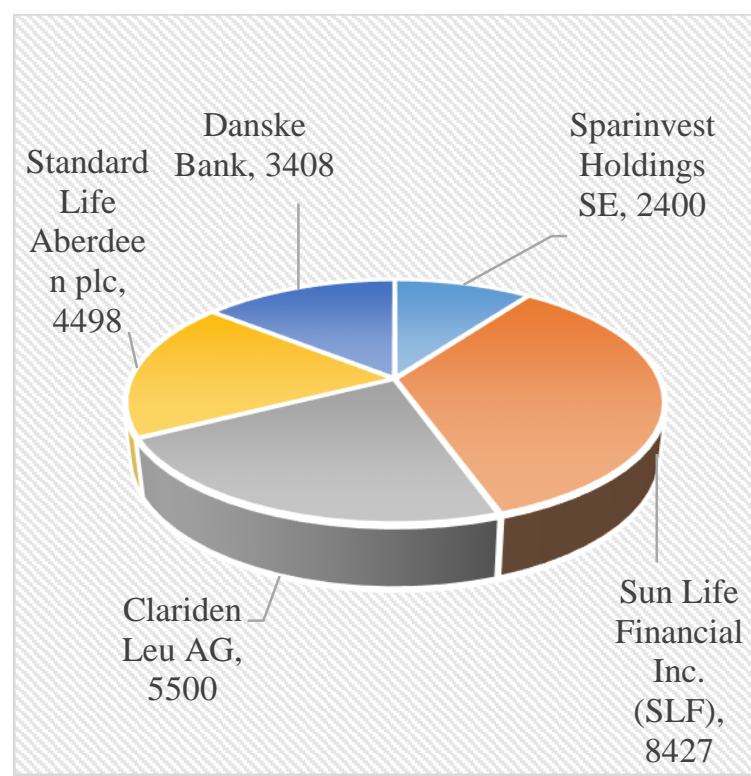

the UK and Danske Bank of Denmark. In addition, the analysis of the sale of the bank's Eurobonds by industry shows that the highest share was accounted for by financial advisers (59\%), commercial banks (26\%) and insurance companies

$(15 \%)$

(Figure

5).

Figure 5. Analysis of companies and industries that purchased Eurobonds of Uzpromstroybank JSCB

While the Bank's initial price and yield were high after the successful placement of Eurobonds in 2019, it can be seen that the yield on Eurobonds has been declining since March 2020 due to the global pandemic.

\section{CONCLUSION}

Today, in the context of developing the practice of attracting financial resources from the international capital market by joint-stock companies of Uzbekistan, it is necessary to involve not only commercial banks but also enterprises of the real sector of the economy in these processes. By improving this practice, the gradual reduction of the state's share in the charter capital of these joint-stock companies will have a positive impact on strengthening integration into international financial markets, gaining independent international rating indices and developing a modern corporate governance mechanism.

The goals of the government in issuing sovereign international bonds on the international market are not only to provide the economy with investment funds, but also to place sovereign international bonds in international financial markets, to achieve international recognition of Uzbekistan's economic potential, creating a benchmark for Uzbekistan. It was concluded that banks will be able to place their bonds in world financial markets and on this basis to create a basis for independent financing of investment projects.

The tendency of commercial banks to participate as the largest institutional 
investors in the emerging securities market is explained by the fact that many of them have a high level of capitalization, strong databases on the status of its various segments, as well as qualified specialists in investment management. Having such important criteria of competitiveness opens up many opportunities for commercial banks of Uzbekistan to use a wide range of tools to finance innovative development programs of enterprises of the republic. It should be noted that commercial banks are the most experienced and investment institutions in the stock market of Uzbekistan. In addition to the above, the need of banks to expand the range and improve the quality of services for enterprises is associated with the emergence of serious competitors in the financial market of Uzbekistan in the form of more economically viable financial structures (investment funds, insurance).

\section{REFERENCES}

1. Uzbekiston Respubliki Presidency 2018 yil 21 yuldagi "Таshқі moliyalashtirish manbalarini diversificationlash by̆yicha қy̆shimcha chora-tadbirlar turisida" gi 3877-sonli karori.

2. Kasimova, M.I. Capital market: essence, content and its place in the system of market relations / M.I. Kasimova /I Fundamental research. - 2016 .-- S. 152-156.

3. Lapshina ZV, Praht KS Capital market: structure and functions // Economy and society - № 2-3 (15). - 2015 -- p. 141-145.

4. Perridon L. Finanzwirtschaft der Unternehmung / L. Perridon. M. Steiner, Munchen: Verlag Vahlen, 2008. S. 150.

5. Rubtsov B.B. Global financial markets: scale, structure, regulation // The Age of Globalization. - No. 2 (8) - 2011. - P.73-98.

6. Modern financial markets: monograph; ed. V.V. Ivanova. - M .: Prospect, 2014 -- 572 p.

7. Frederics S. Mishkin, Kent Matthews and MassimoGiuliodori. Financial markets and institutions. USA. Prentice Hall, 2012. P. 2.
8. Abdullaev SP Directions for using the potential of the financial market in ensuring economic growth in the country https://uba.uz/uz/press_center/publication s/3054/38260/

9. Burkhanov A.U., Hamdamov O.N. Financial management. Textbook. - T .: «Innovative development publishing house», - 2020, 468 pages.

10. http://cbu.uz/oz/statistics/financing/73901/ - Based on the official website of the Central Bank of the Republic of Uzbekistan.

11. https://uzse.uz/ - RFB “Tashkent" for 20162019. based on the author's reports.

12. http://www.cbu.uz/oz/- Prepared on the basis of the Central Bank of the Republic of Uzbekistan.

13. https://www.asakabank.uz/uz- 2014-2019 of Asaka Bank. prepared by the author on the basis of reports.

14. https://uzpsb.uz/upload/filesY̌zsanoatqurilishbank Prepared on the basis of the official website of ADB. 